\title{
Bermuda's balancing act: The economic dependence of cruise and air tourism on healthy coral reefs
}

Pieter van Beukering ${ }^{a^{*}}$, Samia Sarkis ${ }^{b}$, Loes van der Putten ${ }^{c}$, Elissaios Papyrakis ${ }^{a, d}$

a Institute for Environmental Studies (IVM), Faculty of Earth and Life Sciences (FALW), VU University, Amsterdam, The Netherlands

b Department of Conservation Services, Government of Bermuda

c Social and Sustainability Innovation, Sunldee, Amsterdam, The Netherlands

d School of International Development, University of East Anglia, Norwich, UK

* corresponding author - [pieter.van.beukering@vu.nl]

Abstract

Although Bermuda has to date managed to achieve equilibrium between tourism and coral reef conservation, this delicate balance may be threatened by the growth and changing face of the tourism industry. This may result in negative impacts on the coral reefs and services provided by this valuable ecosystem. The reef-associated value to Bermuda's tourism industry was determined, distinguishing between the added value of cruise and air tourism. Economic valuation techniques used were the travel cost method, the net factor income method, and the contingent valuation method. Results show that coral reef value to tourism in Bermuda provides an average annual benefit of US\$406 million. Although, cruise ship tourism has been responsible for more than half of the total number of visitors in Bermuda, cruise ship tourist expenditures directly benefiting the island's economy amount to only $9 \%$ of air passenger expenditures. Moreover, the producer surplus for air visitors is twofold that of cruise ship passengers. Despite this low added value of cruise ship tourism in Bermuda, there is a strong drive to accommodate the ever-larger ships built by the cruise industry. Several options have been proposed for the upgrading and re-aligning of existing shipping channels to enable safe and smooth passage; these may lead to environmental impacts, which may in turn affect reef-associated tourism revenue to the island. This study recommends the integration of Bermuda's coral reef value into Cost Benefit Analyses of proposed channel upgrades compared to the "business as usual" scenario. 


\title{
Bermuda's balancing act: The economic dependence of cruise ship and air tourism on healthy coral reefs
}

\author{
Pieter van Beukering, Samia Sarkis, Loes van der Putten, and Elissaios Papyrakis
}

\section{Introduction}

Bermuda, a $55 \mathrm{sq} . \mathrm{km}$ land mass in the middle of the Atlantic Ocean (32N, 64ㅇ) , is densely populated $\left(1,145\right.$ people per $\left.\mathrm{km}^{2}\right)$, and has experienced tremendous economic growth over the last quarter of a century due to two main industries: international business and tourism. Bermuda is an attractive tourism destination, due in part to its excellent infrastructure, easy access, and natural beauty. In 2000, although visitor numbers were lower than what they are today, Bermuda ranked first among all tropical islands worldwide on the basis of tourism density (i.e. the number of tourist days divided by the total land area) (McElroy, 2003). Tourism accounts for an estimated contribution of $\$ 658$ million to Bermuda's GDP, or approximately 12\% (Department of Statistics, 2011). In 2013, around 580,000 tourists visited Bermuda, of which 340,000 came by cruise ship and 240,000 arrived by air (Bermuda Department of Tourism, 2014).

Although cruise tourism was initially characterized globally by its rapid speed of development and noted for more than two decades of high growth levels, the North American market on which Bermuda depends has demonstrated a slower rate of growth, with a decline in its share of the global cruise activity in terms of both passenger numbers and spend (Weeden et al., 2011). The sector's continued commissioning and bringing into service ever-larger ships, able to offer extensive range of facilities and onboard activities is evidence of the sector's competitive nature and emphasis placed on sales promotion. However, one of the challenges faced by the cruise sector concerns the destination's ability to cater for larger ships. The pressure placed on Bermuda as a destination port to accommodate the changes in the cruise ship industry challenges the delicate balance between maintaining a crucial tourism industry and preserving its natural marine environment. The island has to date managed to achieve such an equilibrium, yet it is questionable whether this equilibrium will remain in face of the perceived need to accommodate the cruise sector.

More specifically, the Ministry of Public Works is considering the upgrade of Bermuda's shipping channels to allow safe passage for the cruise lines currently servicing the island and for the newer, larger Quantum class of cruise ships. The scope of potential impacts resulting from infrastructure development and cruise ship operations on Bermuda's environment include the direct destruction of reefs for enhanced passage, indirect impact from dredging activities on surrounding reefs and seagrass meadows (Lewis et al., 1985), pollution and sedimentation of shipping channels (Jones, 2011), increased potential in grounding of boats, and lastly a longer term repercussion on both sectors of the tourism industry, as quality of visiting experience declines with poorer reefs (Sarkis, 1999; Price, 2006). For these reasons, attention needs to be given by decision-makers, not only to understanding the potential implications 
from environmental and socio-economic perspectives, but also in terms of how it might affect the current air tourism market.

Against this background, an immediate concern for Bermuda's marine ecosystem is the lack of "formal" procedure for assessing developments that impact the coral reef system surrounding the island. The current study addresses this by providing a tool for incorporating environmental considerations in policy-making, and informs decision-makers on the dependence of tourism on a healthy environment. The specific objective of this study is to analyze and quantify the economic contribution of Bermuda's coral reefs to tourism, distinguishing clearly between cruise tourism and air tourism. This study contributes to the analysis of the relationships between the quality of the coral reef environment, the volume of cruise and air tourism, and the value of cruise and air tourism directly contributing to the island's economy. The study is novel in its approach as it aims to determine the importance of coral reefs for the cruise and air tourist industry and for its visitors through perception and valuation surveys. Especially for cruise tourism, this addresses an issue that constitutes an important hole in the literature (Johnson, 2002). Therefore, the study provides a sound tool for the long-term conservation of natural resources and helps to identify and implement more sustainable policies and activities, thus balancing environmental, social and economic goals.

The paper is structured as follows. Section 2 describes the environmental and economic context of the tourist industry in Bermuda. Section 3 explains the methodology developed for this study involving surveys applying various valuation techniques (i.e. contingent valuation and the travel cost method). Section 4 shows the results of both surveys highlighting the differences between the cruise tourism and the sector targeting air visitors. Section 5 concludes the paper and formulates policy recommendations for the long-term conservation of Bermuda's valuable marine resources.

\section{Background}

The environmental issues of tourism are complex, more so than those in many other industries. Tourism production and consumption both have either positive or negative environmental consequences. At the same time, tourism activities are often affected by the quality of environmental resources (Tribe, 2011), a dilemma also faced by Bermuda's tourism. Bermuda is a destination to both cruise and air visitors. As shown in Figure 1, cruise tourism surpassed land-based tourism in 2006, when just over 336,000 tourists arrived by cruise ships as compared to 220,000 by air (Teye, 2006), and continues to grow at around 5\% per year (Bermuda Department of Tourism, 2007a). This became the turning point in a major shift from air visits to cruise visits; air arrivals peaked in 1987, constituting $76 \%$ of total tourism (476,859 visitors) at this time, but declined to 36\% in 2011 (236,038 visitors), contrasting with the increase contribution of cruise tourism (63\%) to total visitor arrivals $(415,711$ visitors, in 2011$)$. This shift has had a major impact on the whole sector, creating an imbalance between air and cruise arrivals with repercussions on the hotel supply which decreased by $44 \%$ (Bermuda Department of Tourism, 2012). 


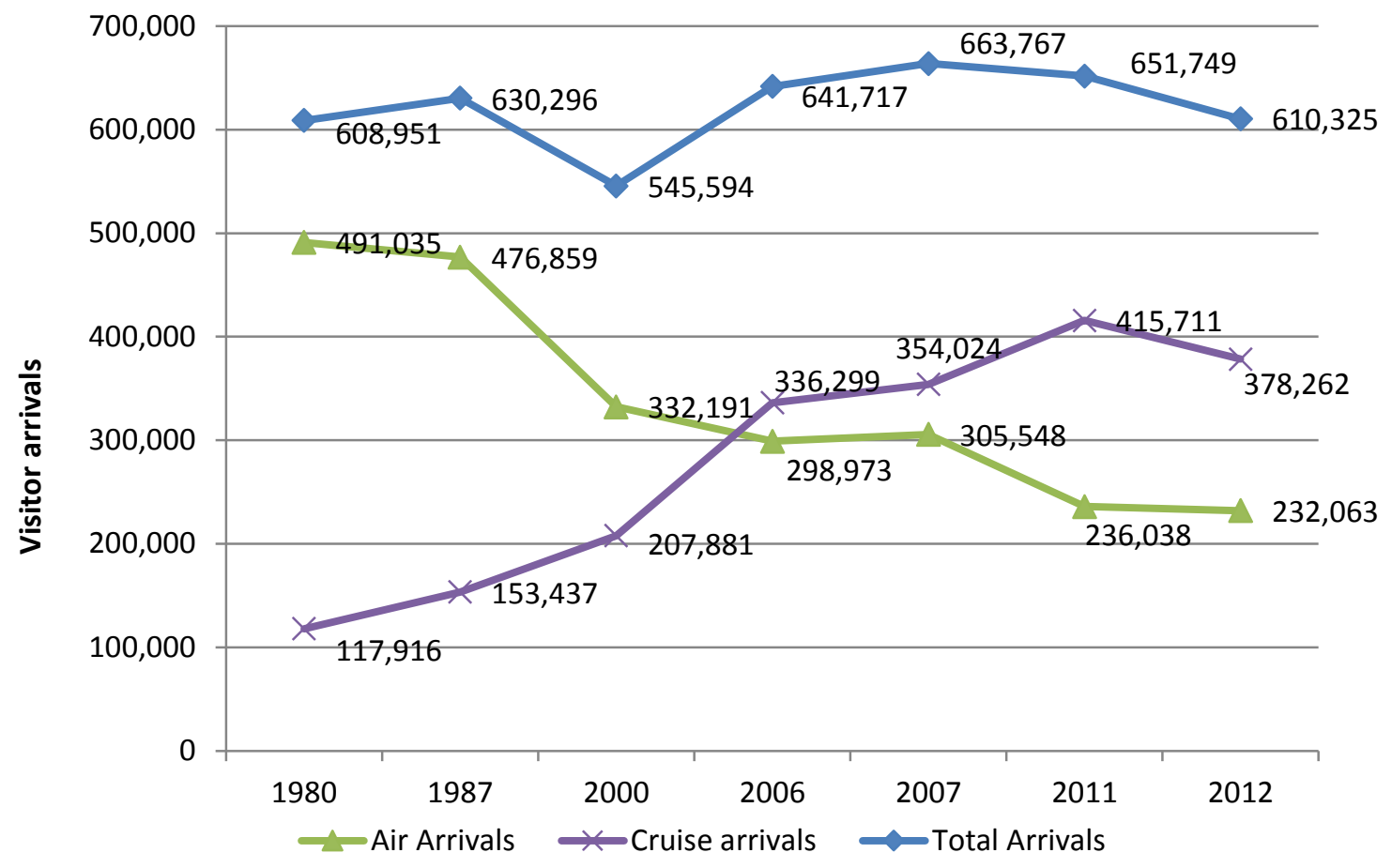

Figure 2. Visitor arrivals in Bermuda for the period 1980 to present.

Reasons for the decline of air arrivals may not be directly associated with increases in cruise arrivals, however, Bermuda's carrying capacity in terms of the number of tourists per day is a limiting factor in both the total number of arrivals and in the evaluation of an optimal tourist strategy. Bermuda's capacity was first established at half a million visitors annually, based on physical carrying capacity levels (Clark, 1995). Next, a 3-year policy was put in place by the ministry of transport of Bermuda, setting a passenger limit of 6,000 passengers per day (Sarkis, 1999). Subsequently, Price (2006) reported that Bermuda's policy allowed for a maximum of 10,000 cruise visitors per day in 2005 . The underlying basis for the daily maximum set forth by Bermuda's policies is unclear, and although carrying capacity is a straightforward concept, arriving at a realistic quantitative estimate is difficult. As shown in Table 1, the fact remains that the total visitors to residents ratio has been increasing since 2008 , directly reflecting the increase in cruise passengers to residents ratio (6.42), attributed to the increase in growth rate of $19 \%$ for this sector. Bermuda ranks $7^{\text {th }}$ out of 21 Caribbean islands with respect to the penetration ratio (Price,2006), but more importantly these authors ranked Bermuda $1^{\text {st }}$ in terms of the density ratio indicating that there are more tourists-days spent on Bermuda per square kilometer of land area than any of the other 20 Caribbean islands examined. Note that in order to obtain a tourist density ratio equal to the median of the islands examined, Bermuda would have to reduce its number of tourist-days by approximately a factor of 10 . Although it is unknown whether the other islands are within sustainability limits, it appears that Bermuda has been facing more visitor "pressure" per square kilometer than other Caribbean islands (Price, 2006). 
Table 1. Change in tourism intensity indicators for Bermuda in the period 2008 and 2012

\begin{tabular}{|l|c|c|c|c|c|}
\hline Indicator & $\mathbf{2 0 0 8}$ & $\mathbf{2 0 0 9}$ & $\mathbf{2 0 1 0}$ & $\mathbf{2 0 1 1}$ & $\mathbf{2 0 1 2}$ \\
\hline Total visitors* & 550,021 & 554,394 & 580,193 & 651,749 & 610,325 \\
\hline Growth rate (\%) & $-17 \%$ & $1 \%$ & $5 \%$ & $12 \%$ & $-6 \%$ \\
\hline Air Tourists & 236,613 & 235,866 & 232,262 & 236,038 & 232,063 \\
\hline Growth rate (\%) & $-14 \%$ & $-11 \%$ & $-2 \%$ & $2 \%$ & $-2 \%$ \\
\hline Cruise ship passengers & 286,408 & 318,528 & 347,931 & 415,711 & 378,262 \\
\hline Growth rate (\%) & $-31 \%$ & $1 \%$ & $10 \%$ & $19 \%$ & $-11 \% * \star$ \\
\hline No. of air tourists nights spent & 6.4 & 6.1 & 6.2 & 6.1 & 6.1 \\
\hline Bermuda population & 65,462 & 65,811 & 64,319 & 64,722 & 64,867 \\
\hline Air tourists to residents ratio & 4.0 & 3.6 & 3.6 & 3.7 & 3.6 \\
\hline Cruise tourists to residents ratio & 4.4 & 4.8 & 5.4 & 6.4 & 5.8 \\
\hline Total visitors to residents ratio & 8.4 & 8.4 & 9.0 & 10.1 & 9.4 \\
\hline Tourism penetration ratio & 70.6 & 59.8 & 61.4 & 60.6 & 59.7 \\
\hline Tourism Intensity ratio & 85.1 & 72.4 & 72.7 & 72.0 & 71.2 \\
\hline
\end{tabular}

Source: Compiled from data retrieved from Environmental Statistics Compendium (2013), Department of Statics, Government of Bermuda

* Does not include yacht passengers

** The decrease of cruise ship passengers recorded between 2011 and 2012 is attributed to cancellations by cruise ships due to ship issues and dock repairs.

\section{Cruise ship tourism in Bermuda}

Bermuda has been a popular destination for cruise ships since the early 50 s, mainly as a result of its proximity to the Eastern seaboard of the United States. There are three ports, St. Georges, Hamilton and Dockyard, with four main shipping channels (North and South, Two Rock Passage and Town Cut). The majority of cruise ships calling Bermuda until 2004 were relatively small cruise ships (length and beam less than 692 feet and 100 feet respectively), berthing initially in Hamilton and St. Georges, and later in all three ports. The re-development of the former British Naval Dockyard as a dedicated port for Panamax and Post-Panamax ships was completed in 2005. At this time, larger ships, including postPanamax vessels started visiting Bermuda regularly, berthing in Dockyard, and smaller "luxury" cruise ships occasionally call on the island, restricting visits to one or two a year for the most part. The size of cruise ships continues to increase (Post-Panamax), and although to date, they have used the North Channel instead of the smaller most used South Channel, passage is not deemed safe, especially under adverse weather conditions (Smith et al., 2013).

Cruise tourism contributes annually to the Bermudan economy through on-land expenditures of cruise ship passengers, service fees to the Department of Marine and Ports, docking fees to the corporations, and through passenger tax varying between $\$ 60-\$ 80$ per passenger (Price, 2006). In 2011, cruise arrival expenditure amounted to US\$65 million. This is notably less than the US\$365 million estimated for air arrival expenditure in the same year, despite the markedly lower percentage of air arrivals recorded (see Figure 1)). These numbers concur with the recognition that despite a general assumption that cruise tourism benefits the local economy (Kido and Kido, 2008), often this industry contributes considerably less than tourism based on air arrivals (Patullo, 2004; Shamsub et al., 2006; Seidl et al., 2007). 
Bermuda's coral reefs have long been considered a key component of the island's natural wealth, as well as a prime marine asset for attracting visitors, contributing to $86 \%$ of the key on-island activities (Bermuda Department of Tourism, 2007b). Enjoying the beach, swimming and snorkeling are popular activities, with glass bottom boat tours being the most popular among cruise ship passengers.

\section{Bermuda's coral reefs}

One of the northernmost coral reef systems in the World, Bermuda's reefs lie in the northwest of the Sargasso Sea, and are isolated by distance, deep water and major ocean currents from North America, (1060 km ESE from Cape Hatteras, and 1330 km NE from the Bahamas). The marine environment owes its subtropical characteristics to the proximity of the Gulf Stream flowing west of the island and the prevailing conditions of the Sargasso Sea (Steinberg et al. 2001). Lying on the southern rim of the largest of three steep-sided sea-mounts on top of the volcanic pedestal, the shallow-water Bermuda platform comprises a limestone cap, encompassing an area of approximately $1000 \mathrm{~km}^{2}$.

The economic value of coral reefs to Bermuda was determined within well-defined geographic boundaries. The study area, estimated to be $400 \mathrm{~km}^{2}$, approximately half of the total estimated reef surface area excludes reefs on the outer edge of the North Lagoon, or fore-reef slope reefs (Figure 2). The geographical boundary selected for this study was based in part on tourism use. Bermuda's reefs are typical of high latitude reefs, with a low level of live coral coverage; the average surface coral cover on the North Lagoon is less than 44\%, based on hard corals only (Murdoch, 2007).

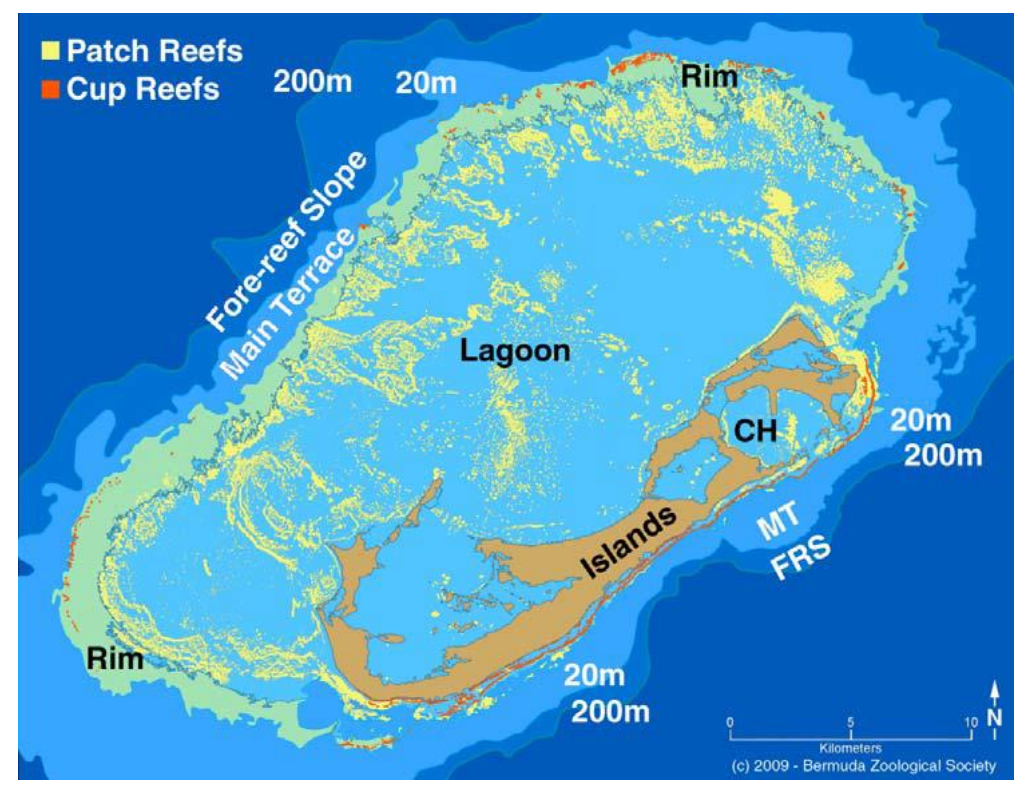

Figure 2. Bermuda reef chart identifying different reef types and boundary of study

Source: Sarkis et al., 2010.

Although considered to be one of the healthiest and most pristine reefs of the wider Caribbean Region, Bermuda's reefs have been classified as at "High Risk" by the World Resources Institute (Burke et al., 2008). This is attributed in great part to the island's high population density existing within $20 \mathrm{~km}$ of the 
coral reefs, and the increasing threat potential associated with shipping traffic and coastal development. This concurs with assessments of several impacts in Bermuda's waters, namely that of Castle Harbour 50 years after dredging for the airport construction, assessments of ship groundings (Murdoch, 2007; Jones, 2011) and pollution and sedimentation in shipping channels (Jones, 2007; Jones, 2011).

\section{Potential threats}

The more immediate threat to Bermuda's Coral Reefs involves the response to the advent of larger cruise ships. This threat is twofold: 1 ) The dredging and modification of the shipping channels and landing docks directly impacting targeted reefs, and indirectly impacting surrounding reef ecosystem through spillover of development activities, and 2) the subsequent potential routine cruise ship movements in the North Channel, generating plumes, demonstrated to significantly increase the turbidity of the inter-reef lagoonal seawater in Bermuda, as compared to natural background levels caused by wind and wave re-suspension (Jones, 2011). Regarding the latter, regular re-suspension of sediments affecting coral species diversity has been documented by Murdoch (2007) for the well used South Channel, and constitutes a risk to the associated coral communities, concerning not only adult colonies of coral reef species, but also successful settlement of coral planulae leading to a gradual loss of existing coral community with a longer term effect on the whole ecosystem (Jones, 2011).

Regarding the first threat, the modification of the shipping channel to allow safe passage for the larger Quantum class cruise, the area under investigation covers the eastern end of Bermuda, off the town of St. George's, as well as the central part of the North Lagoon (BEC 2014). Bermuda's navigational channels allow shipping to enter through the fringing reefs encircling the island via The Narrows, a dredged channel to the northeast of St. George's Island. Once within the relatively protected waters of the North Lagoon, shipping can transit either the North or South Channels to proceed to berths either at Dockyard of Hamilton. There are three options considered, a) the re-alignment of the North Channel, b) the upgrade of the existing route of the South Channel and c) the re-alignment of the South Channel. For all three options, dredging of the Narrows to a minimum depth of 12.5 meters is required, with a projected volume of $8000 \mathrm{~m} 3$ of material removed. In addition, removal of reef along the western margin of the channel is required to increase the width to a minimum of 190 meters (BEC, 2014). The proposed methodology calls for the removal and translocation of all corals that would be directly impacted and the dredging involves the removal of limestone and coralline rock, with a projected large plume of fine particulate material produced. ${ }^{1}$

Another threat is the potential increased frequency of grounding with passage of larger ships, resulting in severe localized biological and physical damage (Jaap, 2000), leading to turbidity plumes following

1 For option a) reefs are proposed to be removed near the northernmost part of the Crescent where the first turn is located, at White Flat, and at Brackish Pond Flat. Total amount of dredging spoils estimated are $416,900 \mathrm{~m} 3$ for option a. For options $b$ and c, significant dredging of soft and hard material is required (a total of 4.16 million $\mathrm{m}^{3}$ ), and although no corals are found along this path, corals nearby may be impacted by sedimentation (BEC, 2014;www.channelstudy.info); the extent to which nearby corals will be impacted depends on the dredging method and is uncertain at this time. 
subsequent efforts to remove the ship from the reef, chemical contamination of sediment with antifouling paint from the ship's hull, and continuous slow-release of biocides preventing settlement of marine organisms affecting reef health for the long term (Jones, 2011). It should be noted that the timescale associated with natural recovery can be in the order of decades or more (Precht, 1998).

To date conservative measures in fisheries management and legal protection of Bermuda's coral reefs (Coral Reef Preserves Act, 1977; Protected Species Order, 1978) have ensured that Bermuda's reefs retain their healthy status. A recent report (August, 2011) (commissioned by the Bermuda Ministry of Transport to assess the ability of Bermuda's shipping channels to accommodate larger cruise ships) is a clear indication of the government's interest to promote the expanding cruise tourism on the island. This changing cruise ship industry, and more specifically that of the cruise lines serving Bermuda, forces a re-evaluation of the island's carrying capacity, a scenario which has been faced by a number of additional Caribbean destinations, such as the Cayman Islands (Shamsub et al., 2006), the Bahamas and Mexico's Yucatan Peninsula (Patullo, 2004). Much of the literature today appreciates the importance of developing tourism 'sustainably'. This recognition has led to the emergence of 'Responsible' tourism which addresses: a) tourism's impact on the environment, b) the equitable distribution of economic benefits to all segments of a tourist destination, and c) minimizing negative socio-cultural impacts.

The recent request made by the government of Bermuda for an Environmental Impact Assessment on shipping channel modifications is a positive step towards enhanced transparency in decision-making, yet the lack of policy and "formal" procedure when assessing developments which have a potential impact on the marine environment, and the absence of a mechanism for integrating environmental values remain a concern. The current EIA does not include any additional modifications to Town Cut and Two Rock Passage necessary to allow access to St. George's and Hamilton (previously two popular cruise destination ports) by larger vessels. This economic valuation study provides the means to consider the long term multiple benefits provided by the coral reef system, servicing not one but many community groups.

\section{Methodology}

Data were collected through available documentation published by the Department of Tourism, and through empirical research. For the latter, two surveys were designed and distributed specific to this study: 1) A reef-associated tourist operator survey providing costs and revenue data, and 2) a tourist exit survey assessing the importance of coral reefs to the visitation experience (see Figure 3 ). The economic analysis used to estimate the tourism value of Bermuda's coral reefs involves three methods: a) the net factor income method, resulting in the "producer surplus", or the value of the coral reef ecosystem in the production of a marketed good generated through paid activities such as SCUBA diving and snorkeling, b) the travel cost method, a revealed preference method resulting in the "consumer surplus", or the value of the coral reef ecosystem to tourist recreation from the visitor's perspective, and c) the contingent valuation method, providing a "Willingness to Pay" (WTP) value for coral reef conservation, an additional measure of "consumer surplus". It is important to note that the tourism value calculated in this study does not equate the actual contribution of the tourism industry to the 
Gross Domestic Product (GDP) of Bermuda but instead represents the societal value of coral reefs via the tourism industry in its broadest sense.

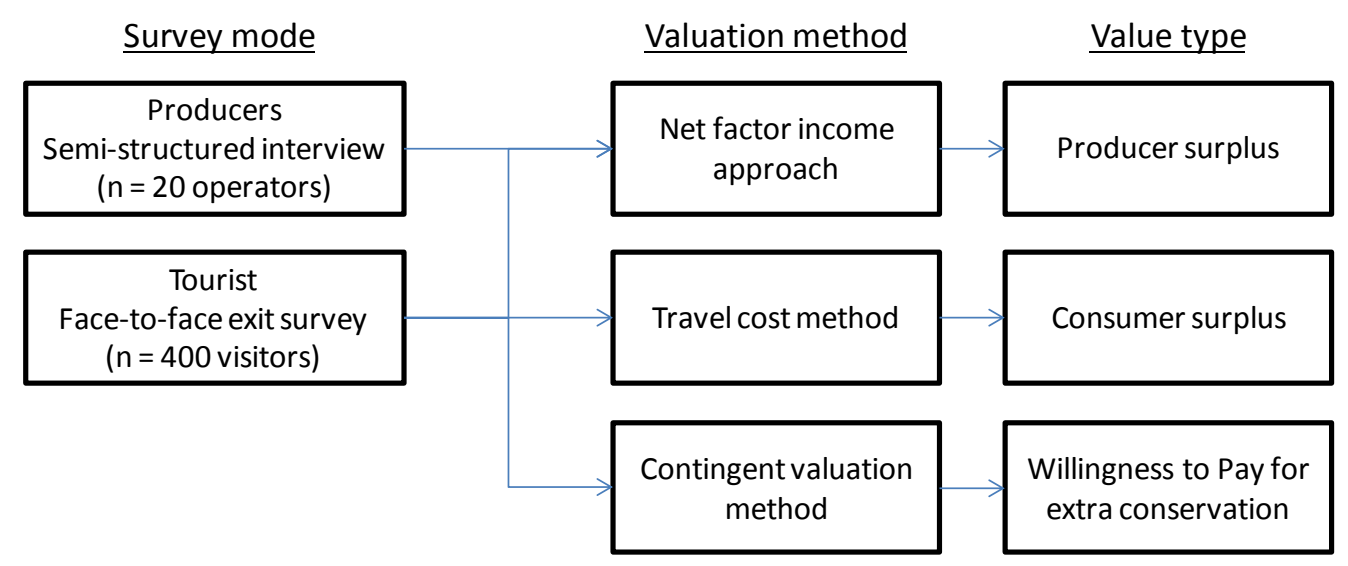

Figure 3. Methods used to value consumer surplus, producer surplus and 'willingness to pay' contributed to by tourists for coral reef-associated activities.

\section{The net factor income method}

The net factor income method is applied to estimate the value of ecosystem services as the total surplus between the revenues and the cost price of production (Van Beukering et al., 2007). The net factor income method is appropriate in a situation where an ecosystem provides a service which leads to an increase in producer surplus (Woodward and Wui, 2001). In this study, the net factor income method is based on the actual expenditures of tourists who visit Bermuda's coral reefs. Expenditures are categorized by type of expenditure, depending on the intensity of use of the ecosystem. For example, specific expenditures related to coral reef-related activities (snorkeling, diving) can be distinguished from other travel expenditures. The assumption is that total reef-related tourist expenditures equal total reef-related revenues from entrepreneurs in the industry. By deducting capital costs, the remaining profits are considered as the "producer surplus" of the tourism related value of the ecosystem.

Two issues are relevant in estimating the producer surplus of tourism-related ecosystem services. The first issue relates to the percentage of the profit of direct and indirect reef-related producers or operators which can be considered as value added (i.e. an increase in producer surplus). Due to a lack of information specific to the Bermuda case study, percentages calculated for other similar studies are used. For example, a similar coral reef valuation study in Hawaii demonstrated that $25 \%$ of all direct and indirect reef related expenditures can be considered as value added (Van Beukering and Cesar, 2004). The second issue relates to the indirect reef-related expenditures. Not all tourists visit a tropical island for one single purpose. Therefore, not all expenditures can be related to the marine ecosystem. Cesar and van Beukering (2004) developed a method to estimate the percentage of travel expenditures to be allocated to the coral reefs at a particular destination, by asking visitors about the reasons contributing to their motivation to choose a particular destination. This allocation method was also applied to this study. 
Data on the direct value generated from coral reef tourism was compiled from information given by tour operators. There are 40 reef-associated tour operators in Bermuda. Thirteen of these operators were interviewed face-to-face, including all SCUBA dive operators $(n=5)$, three glass bottom and rental boat operators, and two charter boat operators. The questionnaire was designed to obtain data on the gross revenue and costs associated with reef recreation, a measure of the type of tourists attracted to reefrelated activities, and an additional estimate of the perceived threats and solutions to ensure continued visitor satisfaction.

\subsection{Travel cost method}

The travel cost method (TCM) is used to estimate the "consumer surplus" or the value of ecosystems used for recreation by tourists visiting Bermuda. More specifically, the zonal TCM as opposed to the individual TCM is used in the Bermuda case study, because of the number of trips per person to the "site" (Freeman, 2003). When using the zonal TCM, visitors to a site are divided in zones based on their region of origin. The zones have increasing distance from the visitor's point of departure to the ecosystem analyzed (Van Beukering et al., 2007). The independent variable is the observed number of visitors to the site per thousand inhabitants of the zone of origin, referred to as "visitation rate" (Carr and Mendelsohn, 2003). The dependent variable is the cost of travel. Based on the travel cost information of tourists, the demand for the services provided by the site can be estimated. A demandcurve is calculated and used to estimate the average benefit of the site to the individual visitor, which can be aggregated over the total population to derive the measure of total benefits. There are some issues that must be addressed in implementing and estimating the TCM (Freeman, 2003; Pham and Tran, 2001; Van Beukering et al., 2007).

- Measurement of travel costs: In the case of cruise ship passengers, it is difficult to assess and separate travel costs from the costs of staying on Bermuda. For this reason, in order to have a comparable measure of travel costs between air and cruise visitors, the monetary costs of travel to the site, the time costs of travel and the monetary costs of staying (i.e. accommodation and meals) are included.

- Measurement of international travel by plane: The TCM is originally designed to capture domestic travel to a site, where travel is predominantly by car. To apply the method to long distance destinations, such as Bermuda, the method has to be extended to travel by plane. The challenge is that the distance to the site is not well correlated with the cost of air travel (Carr and Mendelsohn 2003). For the current study, actual airfares were measured thereby representing the actual travel costs for the visitor.

- Functional form of the demand curve: According to Carr and Mendelsohn (2003) the functional form used to fit the data on travel costs can have a major effect on the demand function and thus on the consumer surplus. Because of the small difference between the best non-linear and linear functions estimated, a linear function was used in this study.

- Multi-destination trips: The share of costs incurred by travel attributed to the destination is different for air tourists and cruise ship visitors. All travel time for air tourists are considered as single destination trips, such that travel time is considered functional and not part of the pleasure. For cruise passengers, the travel time at sea is considered as "half the pleasure" of the trip, and 
hence not related to the destination; for this reason, it is considered as another destination and relates to $50 \%$ of total travel costs incurred to visit coral reefs. Furthermore, in some instances, Bermuda is only one of four destinations during a given cruise. In such cases, travel costs incurred to visit Bermuda are assumed to be one fourth of total travel costs related to the destination.

- Multi-purpose trip: Since visitors tend to visit a location for several reasons, only part of the travel costs can be allocated to the site valued, namely coral reefs. In this study the percentage of travel costs allocated to the coral reef value is estimated by assessing the percentage of anticipated reefrelated activities contributing to the motivation for travelling to Bermuda.

\subsection{Contingent valuation method}

The contingent valuation method (CVM) is used to estimate the WTP for nature conservation of the marine ecosystem of Bermuda. It is recognized that CVM has a number of biases, namely strategic, design, hypothetical and operational bias (Pearce and Turner, 1990). The most relevant in this study is the design bias which may result from three sources.

Firstly, the starting point bias, referring to the starting bid of the interviewer, may influence the respondent. Questions related to WTP can be open ended (i.e. minimizing the starting point bias) and closed ended (i.e. dichotomous or payment card). Results from contingent valuation studies vary, with some finding a correlation between starting point and respondent's bids and others not. In this study, a payment card elicitation method is applied to minimize the design bias, following guidelines of Rowe et al. (1996).

Secondly, the information bias results from how information is presented to the respondent; where the amount, quality and sequence of information may influence the respondent. In this survey, respondents were familiarized with the topic through a series of questions on nature based activities, perception of ecosystem health and potential threats. Thereafter, the WTP question was introduced as follows: "Let's go more in depth on how you appreciate Bermuda's coral reefs. At this moment the coral reefs around Bermuda are beautiful and healthy. However there are some threats caused by human activity that can change that. One of them is the increased pressure from tourism. If these threats are not dealt with, they can damage the reefs. This would ultimately mean losing Bermuda's beaches and blue waters. To help preserve the coral reefs of Bermuda, extra funds may be needed for which tourists may be asked to pay." This process of preliminary questions followed by a short informational text, addressed the information bias effectively.

Thirdly, a vehicle bias may result from the sensitivity of respondents to the payment mode (e.g. taxes, entrance fees, surcharges, higher prices). For example, a payment made as a tax may be perceived as being more costly than one made as an entrance fee. In this study, the vehicle bias was addressed by carefully asking a series of WTP related questions. Following the information text mentioned above, general willingness was tested by asking: "Would you - in principle - be willing to pay any amount in addition to your current expenses, to fund activities to preserve Bermuda's coral reef?" If respondents answered positively, the amount was determined with to the following question: "What would be the maximum you would be willing to pay per visit to Bermuda, in addition to your current expenses, to fund activities to preserve Bermuda's coral reef?". This was followed by a question on the preferred method 
to payment (i.e. per visit to Bermuda, per activity, per year) and whether the payment should be voluntary or mandatory. This approach using specific questions addressed the vehicle bias.

\section{Sample description}

A face-to-face tourist exit survey was conducted by six trained professional interviewers during the summer of 2008. A total of 407 questionnaires were completed, surveying 201 (49\%) air tourists and 206 (51\%) cruise ship tourists. Surveys were carried out in the departure lounges of the International Airport as well as at the three existing cruise ship terminals. This ensured that respondents completed the interview following their complete visitation experience in Bermuda. Only visitors coming to Bermuda for leisure were surveyed. Answers were recorded on the questionnaire, entered in a database and analyzed with SPSS and STATA.

A full description of the survey results on the tourists visiting Bermuda, their origin, and the description of their trip is given in Sarkis et al. (2010). Equal numbers of male (52\%) and female (48\%) tourists were surveyed, of which $50 \%$ have a university or college degree and $28 \%$ have a master or other advanced degree. The majority (80\%) is employed, earning an average gross household income of US\$120,000. The average age of the respondent is 48 years and the household composition is 2 adults and 0.8 children under 18 years. Most tourists come from the East Coast of the U.S.A. This is especially the case for cruise ship tourists (95\%). Air tourists surveyed were in Bermuda for the $4^{\text {th }}$ time and cruise ship tourists for the $2^{\text {nd }}$ time. $33 \%$ of air tourists booked their trip as a package which includes flight and accommodation. $100 \%$ of all cruise ship tourists' travel arrangements are packages. Results relating to tourists origin are in agreement with those reported by the Department of Tourism (2007a) but differ slightly for the length of stay on Bermuda. The survey indicates that air passengers stay 7 days (rather than 5.4) and cruise ship passengers stay 2 days (rather than 4) (Department of Tourism, 2007a).

Another important difference between cruise ship and air tourists is the importance of the "health" and pristine appearance of coral reefs in Bermuda. Both air and cruise ship tourists consider the coral reefs (rather than associated fauna) as the largest attraction by visiting divers and snorkelers. The sighting of reef fish ranks a close second as a tourism asset. For reasons of simplification, it is assumed that wrecks are not reef-related although several wrecks in Bermuda are located in reef areas and attract reef fish. It is worth noting that of the tourists surveyed, $14 \%$ would not have come if coral reefs were known to be dying or damaged. Extrapolating this percentage to a total of 660,000 visitors reported on the island in 2007 , this translates into a potential decrease of more than 90,000 tourists per year. More specifically, $19 \%$ of cruise ship and $8 \%$ of air tourists would not have visited Bermuda, corresponding to over 66,000 fewer cruise ship passengers and 24,000 fewer air arrivals.

\section{Results}

\section{Producer surplus}

To gain insight into the difference in producer surplus between air and cruise ship tourism, information from both the operator and tourism surveys was combined. The operator survey revealed a mixture of qualitative and quantitative information on the importance of marine ecosystem services from the 
perspective of the private sector. According to the operator survey, most international visitors show sensitivity to the environment, with air visitors being slightly more sensitive than and cruise ship tourists. Such sensitivity is expressed as concern for fish and coral preservation, or in revealing responsible behavior in waste disposal.

Tour operators indicate that the quality of the coral reefs has a high impact on their business. Most of the operators (58\%) report that the quality of Bermuda's coral reefs improved during the last five years, $25 \%$ experienced no change, and $17 \%$ experienced a decline in quality. This remarkable positive view of operators on the marine quality can be explained by the fact that due the fish pot ban in 1990, populations of specific reef fish species increased significantly three years after the fish pot ban (Luckhurst, 1994), which is a trend also observed by the operators. Seeing more reef fish during their dives, possibly leads them to conclude that also reef condition improved. Tour operators consider overfishing as the most important threat to coral reefs, followed by sewage disposal. The impact of cruise ships and coastal development are perceived as minor threats. Operators further consider that water sports bear minimal impact on the reefs, hence they hold minimal responsibility. This is reflected in the fact that only one third of all operators are in favor of an extra visitor fee paid towards the protection of Bermuda's marine ecosystem.

Based on the reported costs by tour operators, the gross profit margin is estimated to be $28 \%$, with personnel, boat maintenance and fuel being the three most important costs $(41 \%, 20 \%$ and $17 \%)$ and amounting to $78 \%$ of total business costs. Diving and glass bottom boat operators generate the most important revenue amounting to $69 \%$ of the direct total reef-associated gross revenues. The direct reefassociated tourism revenue for Bermuda is estimated at US\$7.4 million. Including non reef-associated revenues to this aggregated sum would result in a total revenue of US\$10 million (2007), concurring with earlier estimates by the Ministry of Environment (2000) ranging between US\$7.5-US\$11 million.

In order to estimate the producer surplus of tourism related coral reef services, the net factor income approach is applied, where a percentage of the added value for each type of expenditure is attributed to marine ecosystem services. Due to the lack of information on added value for a number of recreational activities in Bermuda, values are adopted from a similar study on Hawaii's coral reefs (Van Beukering and Cesar 2004). Although Hawaii has less cruise tourism than Bermuda, the profile of the average cruise tourist rather similar from Bermuda since both destinations target US-base visitors. For the expenditures indirectly related to the reef, the added value percentage is applied to only a limited part of the expenditures. The proportion of total expenditures is based on the relative importance of the reefs as assessed by the tourists' motivations to visit Bermuda (36.8\% and $39.7 \%$ for air and cruise ship tourists, respectively). Based on the net factor income calculations the producer surplus for air visitors is estimated at US\$139 per tourist and at US\$55 per tourist for cruise ship passengers (Table 2). Based on 663,767 visitors in 2007 , the reef-related producer surplus value totals US\$62.5 million for that year. The greatest part of this can be attributed to the air tourism sector (i.e.US\$42.9 million per year - more than twofold the value of US\$19.5million per year attributed to the cruise ship tourism sector).

Table 2. Producer surplus visitors to Bermuda

\begin{tabular}{l|rr|rr}
\hline & \multicolumn{2}{|c|}{ Airplane tourists } & \multicolumn{2}{c}{ Cruise ship tourists } \\
\hline Item & Average costs & Producer surplus & Average costs & Producer surplus \\
\hline Flight & $\$ 771$ & $\$ 6$ & n.a. & n.a. \\
Accommodation & $\$ 862$ & $\$ 79$ & n.a. & n.a. \\
\hline
\end{tabular}




\begin{tabular}{|c|c|c|c|c|}
\hline Cruise package & n.a. & n.a. & $\$ 1,089$ & $\$ 39$ \\
\hline Diving & $\$ 19$ & $\$ 5$ & $\$ 5$ & $\$ 0$ \\
\hline Snorkeling & $\$ 12$ & $\$ 3$ & $\$ 17$ & $\$ 4$ \\
\hline Touring the reef & $\$ 7$ & $\$ 2$ & $\$ 11$ & $\$ 3$ \\
\hline Local transportation & $\$ 99$ & $\$ 9$ & $\$ 20$ & $\$ 5$ \\
\hline Meals & $\$ 383$ & $\$ 35$ & $\$ 38$ & $\$ 4$ \\
\hline Total & $\$ 2,153$ & $\$ 139$ & $\$ 1,180$ & $\$ 55$ \\
\hline
\end{tabular}

\section{Consumer surplus}

To assess the value of coral reefs used for recreation in Bermuda, the zonal TCM was used, based on the assumption that the travel expenses incurred to visit a site represent the price of access to the site (Van Beukering, et al., 2007). Eight zones were defined, based on travel time to Bermuda (Table 3). Given the number of visits to Bermuda and the population for each zone, visitation rate (i.e. the number of visits to Bermuda per thousand inhabitants for each zone) can be calculated. Average travel costs incurred by tourists to visit Bermuda, as given in Table 3, were calculated based on the components outlined in Table 3. Data for TC1 (flight/cruise, accommodation, meals) and TC2 (other expenses in Bermuda) were obtained from the current study's tourist exit survey. TC1 is a combination of transportation costs to the destination, accommodation and meals; it is difficult to separate these three costs for tourists travelling on a package - particularly in the case of cruise passengers. TC2 includes travel costs within Bermuda, expenses for tours (e.g. snorkel and dive trips), and other costs (e.g. souvenirs). TC3, TC4 and TC5 are calculated on the basis of the place of residence of the respondent, port of embarkation, type of transportation to Bermuda, household income and working hours. Costs of travel time are considered relevant for those tourists who are employed only, as travel time is an opportunity cost if holiday time is limited. The means of all five types of travel costs are substantially different for air and cruise ship tourists.

Table 3. Travel zones for visitors to Bermuda with associated travel costs.

\begin{tabular}{l|rrrr}
\hline Zone & Number of visits & Population (in millions) & Visitation rate $^{*}$ & Travel costs (USD) $^{\text {Past coast }}$ \\
\hline Mid East & 500,708 & 118 & 4,2283 & 1,197 \\
Mid West & 57,647 & 107 & 0,5407 & 1,340 \\
West Coast & 9,882 & 44 & 0,2228 & 1,933 \\
Alaska & 13,177 & 63 & 0,2079 & 1,466 \\
Europe & 1,647 & 5 & 0,3202 & 1,628 \\
Oceania & 77,412 & 736 & 0,1052 & 3,906 \\
Asia & 1,647 & 35 & 0,0471 & 2,813 \\
\hline Total & 1,647 & 4,052 & 0,0004 & 3,627 \\
\hline
\end{tabular}

* Visits per 1,000 inhabitants

** Source of population data: World Development Indicator (2008)

Table 4. Five types of travel cost (per tourist)

\begin{tabular}{l|rr}
\hline Cost category & Air (USD) & Cruise (USD) \\
\hline Flight and/or cruise, accommodation, meals (TC1) & $\$ 2,153$ & $\$ 1,308$ \\
\hline
\end{tabular}




\begin{tabular}{l|rc}
\hline Other expenses in Bermuda including activities (TC2) & $\$ 275$ & $\$ 113$ \\
Travel cost to port of embarkation (TC3) & $\$ 0$ & $\$ 106$ \\
Cost of travel time to port, flight and at sea (TC4) & $\$ 141$ & $\$ 365$ \\
Cost of travel time in Bermuda (TC5) & $\$ 617$ & $\$ 238$ \\
\hline
\end{tabular}

Based on the travel cost information presented in Table 3 and Table 4, the demand for the services provided by coral reefs can be estimated by calculating a demand-curve for the individual visitor, extrapolating results over the total population to derive the measure of total benefits. To estimate the demand curve, two steps are required: (1) a regression on visitation rate per zone and average travel costs incurred by visitors of the zone, and (2) a calculation of the demand function based on the earlier regression.

In Step 1, a linear regression is run on the visitation rate and the travel costs, where the 'Travel costs' is the sum of TC1 (flight, accommodation and cruise), TC3 (travel cost to port of embarkation) and TC4 (travel time to port, flight and sea). For cruise ship tourists, the travel costs are $50 \%$ of the calculated sum, given that only half of the travel costs are related to the destination itself (Bermuda). The other half of travel costs by cruise ship tourists is related to the pleasure of being at sea. Because almost all cruise ship tourists originate from the same zone (i.e. U.S. East coast), and hence incur similar travel costs to Bermuda when using the zonal TCM, it did not prove possible to differentiate air and cruise ship data in the analysis. This homogeneity in data yields no significant relation between travel costs of cruise ships and the visitation rate. Air and cruise ship tourist travel cost data is therefore pooled. Results show a weak relationship between travel costs and visitation rate, which is attributable to the lack of variation in the travel costs within the US sample:

\section{Travel costs $=3,434-624 *$ Visitation rate}

Step 2 involves the calculation of the demand function, based on the above regression. The demand function is based on the total number of tourists who visit Bermuda at the current travel costs, and expanded by estimating the number of coral reef visitors with different additional travel costs:

$$
\text { Additional travel costs }=2,700-246 * \text { Visitors }
$$

The demand-curve obtained for Bermuda is illustrated in Figure 4, enabling the calculation of the consumer surplus - equal to the area under the curve (see the triangle labeled "CS"). These calculations result in a total consumer surplus for Bermuda of US\$896 million, yielding a consumer surplus of US\$1,350 per tourist. The marine ecosystem-related surplus for air and cruise visitors are respectively $36.8 \%$ and $39.7 \%$ and thus the marine ecosystem-related consumer surplus are respectively $\$ 496$ and $\$ 536$ for both visitor groups. These results are in line with earlier studies applying the TCM for coral reef ecosystems (Carr and Mendelsohn, 2003; Carleton and Lawrence, 2005). 


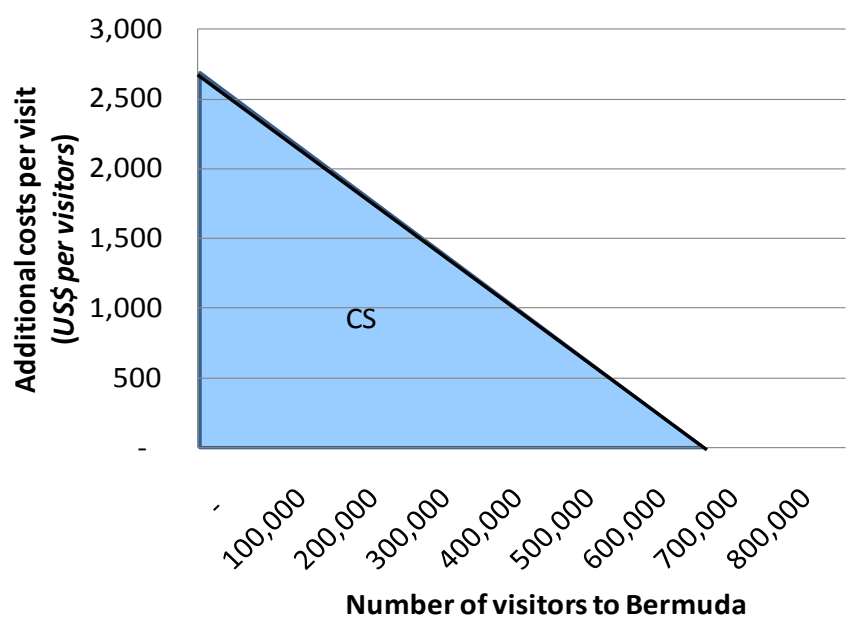

Figure 4. The consumer surplus based on the visitors - travel costs relationship for Bermuda's tourists.

The reef-associated tourism value is estimated based on the percentage of reef-associated recreation, stemming directly (such as diving) and indirectly (such as beach enjoyment) from the coral reef ecosystem. These shares are shown in Table 5 and are combined with the specific visitor information for air and cruise passengers. The reef-associated tourism value from a consumer perspective for the cruise ship sector only approximates US\$190 million, amounting to US\$40 million more than for the air tourism sector. The total (both air and cruise) consumer component of the coral-reef related tourism value of Bermuda's coral reefs in 2007 is calculated to be US\$343 million.

Table 5. Contribution of travel costs incurred by air and cruise ship tourists in Bermuda to access coral reefs for recreation, given as consumer surplus.

\begin{tabular}{l|rr}
\hline & Air & Cruise \\
\hline Consumer surplus & $\$ 1,350$ & $\$ 1,350$ \\
Percentage reef-related & $36.8 \%$ & $39.7 \%$ \\
Reef-related consumer surplus & $\$ 496$ & $\$ 536$ \\
\hline
\end{tabular}

\section{WTP for coral reef preservation}

In this section we explore the variation in the expressed WTP for coral reef preservation across air and cruise ship tourists. Several underlying factors may explain differences in WTP across respondents. For this purpose, we estimate the following generic specification with the use of Ordinary Least Squares (OLS) regressions:

$$
\text { WTP }_{i}=\alpha_{0}+\alpha_{1} \text { Reef Importance }_{i}+\alpha_{2} \text { Relative Reef Importance } i+\alpha_{3} Z_{i}+\varepsilon_{i} \text {, }
$$

where

WTP refers to the expressed WTP for respondent $i$,

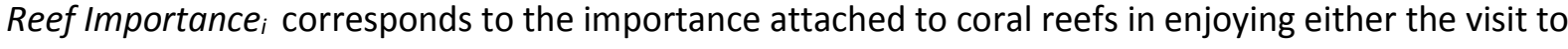
Bermuda or the diving/snorkeling experience more specifically, 
Relative Reef Importance ${ }_{i}$ captures the relative importance of coral reefs with respect to other activities that are likely to contribute to tourist satisfaction,

$Z_{i}$ corresponds to a vector of other control variables likely to explain cross-respondent variation in expressed WTP, and

$\varepsilon_{i}$ refers to the error term.

Results are presented in Table 6. Note that the sample size varies across different specifications and is largely determined by the level of response to the Reef Importance questions; descriptive statistics are provided in the Appendix. Column (1) focuses only on those individuals who expressed a positive WTP. Reef Importance $(s / d)$ captures the perceived significance of coral reefs to the overall experience of diving/snorkeling in Bermuda (at a 1-5 scale). Relative Reef Importance ( $s / d$ ) is the ratio of the importance attached to the coral reef in relation to the average importance attached to other attractions (fish/wrecks/sharks). Airplane Tourism and Method of Pay (per Visit) are dummy variables that take values equal to 1 for airplane tourists and for visitors wishing to pay per water activity (rather than per visit to the island). The variable Duration of Visit captures the total hours of visitation. Further, we include in our specifications the Age of respondent as well as the natural logarithm of his/her Income (in order to minimize the influence of outliers).

Column (2) estimates the same specification for the augmented sample that includes also respondents who did not express a positive WTP for coral reef preservation, which is also the reason behind the variable Method of Pay being dropped in Column (2). Reef importance, both in absolute as well as in relative terms, positively correlates with expressed WTP. For example, according to the results in column (1), the estimated difference in WTP between someone attaching no importance to coral reefs (value 1) and someone attaching the highest importance (value 5) is equal to US\$22.64. Similarly, attaching a twice as large importance to coral reefs in comparison to other water attractions would correspond to a higher WTP by US\$13.21. In comparison to air tourists, cruise ship tourists consistently express a higher WTP. Paying per water activity correlates negatively with expressed WTP, possibly as a result of the adverse psychological effect of repeated regular payments. More wealthy and younger respondents express higher WTP, although the correlations are of low statistical significance. 
Table 6. Variation in WTP across respondents - Regression analysis

\begin{tabular}{|c|c|c|c|c|}
\hline Dependent variable: & $\begin{array}{c}\text { WTPP }_{R} \\
(1)\end{array}$ & $\begin{array}{c}\text { WTPu } \\
(2)\end{array}$ & $\begin{array}{c}\text { WTP }_{R} \\
(3)\end{array}$ & $\begin{array}{c}\text { WTPu } \\
(4)\end{array}$ \\
\hline Constant & -24.23 & -23.48 & -31.79 & -38.72 \\
\hline Reef Importance (s/d) & $\begin{array}{c}5.66^{*} \\
(3.19)\end{array}$ & $\begin{array}{l}5.78^{* *} \\
(2.73)\end{array}$ & & \\
\hline Relative Reef Importance (s/d) & $\begin{array}{l}13.21^{* *} \\
(5.60)\end{array}$ & $\begin{array}{c}9.20^{*} \\
(4.83)\end{array}$ & & \\
\hline Reef Importance (v) & & & $\begin{array}{c}6.24 * \\
(3.58)\end{array}$ & $\begin{array}{c}4.93 * \\
(2.93)\end{array}$ \\
\hline Relative Reef Importance ( $\mathrm{v}$ ) & & & $\begin{array}{l}-3.18 \\
(5.82)\end{array}$ & $\begin{array}{l}-1.08 \\
(5.59)\end{array}$ \\
\hline Airplane Tourism & $\begin{array}{l}-24.26^{* * *} \\
(7.74)\end{array}$ & $\begin{array}{l}-21.69 * * * \\
(5.95)\end{array}$ & $\begin{array}{c}-13.91^{* *} \\
(5.86)\end{array}$ & $\begin{array}{l}-12.11^{* * *} \\
(4.08)\end{array}$ \\
\hline Method of Pay (per Visit) & $\begin{array}{c}-16.57^{* * *} \\
(6.72)\end{array}$ & & $\begin{array}{c}-8.77^{*} \\
(5.02)\end{array}$ & \\
\hline Duration of Visit & $\begin{array}{c}0.43 \\
(0.31)\end{array}$ & $\begin{array}{c}-0.01 \\
(0.02)\end{array}$ & $\begin{array}{c}0.20^{*} \\
(0.11)\end{array}$ & $\begin{array}{c}0.02 \\
(0.04)\end{array}$ \\
\hline Income & $\begin{array}{r}4.10 \\
(6.18)\end{array}$ & $\begin{array}{r}3.15 \\
(5.19)\end{array}$ & $\begin{array}{r}5.05 \\
(3.79)\end{array}$ & $\begin{array}{r}4.46 \\
(3.17)\end{array}$ \\
\hline Age & $\begin{array}{l}-0.40 \\
(0.32)\end{array}$ & $\begin{array}{l}-0.25 \\
(0.25)\end{array}$ & $\begin{array}{l}-0.40 \\
(0.32)\end{array}$ & $\begin{array}{l}-0.01 \\
(0.14)\end{array}$ \\
\hline$R^{2}$ (adjusted) & $0.26(0.11)$ & $0.18(0.08)$ & $0.15(0.07)$ & $0.09(0.05)$ \\
\hline$N$ & 85 & 117 & 183 & 269 \\
\hline
\end{tabular}

Note: WTP $_{R}$ corresponds to the restricted sample that includes only those with a positive WTP. WTPu refers to the unrestricted sample that also includes those with no WTP for coral reef preservation. Robust standard errors of coefficients in parentheses. Superscripts $*, *, * * *$ correspond to a 10,5 and $1 \%$ level of significance. All regressions control for the gender and country of origin of respondent as well as size of household.

Columns (3) and (4) replicate the earlier two specifications of Table 6 but substitute the Reef Importance and Relative Reef Importance indices with two alternative proxies. Reef Importance ( $v$ ) thus captures the perceived importance of coral reef-related activities behind the choice of Bermuda as a tourist destination (at a 1-5 scale). Relative Reef Importance ( $v$ ) is the ratio of the importance attached to these activities in relation to the average importance attached to other attractions (i.e. shopping, sightseeing, playing golf, eating and drinking). Similarly to columns (1) and (2) it can be seen that reef importance and air tourism significantly correlate with the WTP variable.

It is worth noting that the dependent variable ('willingness to pay') is by definition left-censored at 0 and for this reason we have also replicated all regressions of Table 1 using Tobit estimations as an additional 
robustness check. The results are very similar to the OLS estimates presented in Table 6 (both in magnitude and statistical significance ${ }^{2}$ ).

Table 7 indicates whether respondents are in favor of a mandatory rather than a voluntary contribution. The dependent variable is a dummy variable taking the value of 1 when the respondent is in favor of a mandatory payment. Logistic regressions are calculated, given that the dependent variable is binary, indicating that both absolute and relative reef importance are significant predictors of preference for a mandatory payment. All other regressors are statistically insignificant. This suggests that those assigning high importance to coral reefs are not only willing to pay a higher amount for their preservation, but they are also more inclined to have this amount collected as part of a mandatory payment scheme. High bidders often wish to prevent free riders from benefiting from their payments and this is in line with empirical evidence found in other studies (e.g. Brouwer et al. 2008).

Table 7. Preference for mandatory contribution

\begin{tabular}{lcc}
\hline Dependent variable: & $\begin{array}{c}\text { Mandatory } \\
\text { Contribution } \\
(5)\end{array}$ & $\begin{array}{c}\text { Mandatory } \\
\text { Contribution } \\
(6)\end{array}$ \\
\hline Constant & -2.55 & -2.58 \\
Reef Importance $(s / d)$ & $0.62^{* * *}$ & $0.59^{* *}$ \\
Relative Reef Importance $(s / d)$ & $(0.24)$ & $(0.26)$ \\
Airplane Tourism & & $0.54^{*}$ \\
& & $(0.30)$ \\
Income & 0.33 & 0.37 \\
& $(0.47)$ & $(0.47)$ \\
Age & 0.02 & -0.03 \\
& $(0.28)$ & $(0.27)$ \\
Pseudo $R^{2}$ & -0.02 & -0.02 \\
$N$ & $(0.02)$ & $(0.02)$ \\
\hline
\end{tabular}

Note: Robust standard errors of coefficients in parentheses. Superscripts $*, * *, * *$ correspond to a 10,5 and $1 \%$ level of significance. All regressions control for the gender and country of origin of respondent as well as size of household.

\section{Discussion and conclusions}

Bermuda's northernmost coral reef ecosystem is recognized as the island's prime marine attraction, with $38 \%$ of both cruise and air visitors identifying this as a reason motivating their visit. Bermuda is currently faced with the complexities of expanding the tourism industry (and in particular the cruise sector), while at the same time maintaining or growing the air sector, and retaining its natural assets.

${ }^{2}$ Tobit estimates are available upon request. 
This study focuses on the relationship between the coral reef ecosystem and cruise and air tourism on Bermuda, involving both tour operator and tourist exit surveys. Results estimate the reef-associated values which tourists add to the Bermudan economy (travel cost method and net factor income method), and also estimate the WTP of visitors for conservation (contingent valuation method). By distinguishing between the reef-associated tourism values for the cruise and air sector, the study provides an indication as to the economic benefits of each. It highlights the need to integrate the environmental value into decision-making for a better insight into developing a sustainable or, more accurately, a responsible tourism industry.

It is evident that tourists add substantial reef related value to Bermuda's economy, with a total reefrelated tourism value amounting to US\$ 406 million per year. Of importance is the realization that the "pristine" quality of Bermuda's coral reefs is a key component of the tourism industry, determined to be of high impact to the estimated US\$ 7.4 million directly generated from reef-associated tour operator revenue, and based on the high "Reef Importance" attributed by tourists to coral reefs themselves in comparison to other marine assets (i.e. fish sightings, sharks, wrecks). It follows that a decline in the quality of coral reefs will lead to a reduced visitation experience, and a loss of return visitors was calculated to potentially decrease by more than 90,000 tourists per year, with the highest percentage of visitors responding in this way being from the cruise sector.

Furthermore, it is important to note that air tourists add a significantly higher value than cruise tourists, reflected in a twofold difference in the reef-related producer surplus value. This is attributed to the difference in on-island expenditures, calculated to be much lower for cruise ship tourists. However, because the volume of cruise tourists is higher than that of air tourists, the aggregated reef related tourism value per year is comparable for air visitors (US\$197 million) and cruise visitors (US\$209 million).

These results show that cruise and air tourism are very dependent on the state of coral reefs in Bermuda, and therefore the range and quality of this natural resource can influence tourism flow. As seen in previous cases in Bermuda, negative and long-term impacts on the coral reef ecosystem following coastal developments are real and extend beyond the targeted area (Jones 2007; Jones 2011). Over-development can therefore impose not only environmental but also economic costs on industry stakeholders and the wider community. Glasson et al. (1995) described this process as "tourism contains the seed of its own destruction; tourism can kill tourism, destroying the very environmental attractions which visitors come to a location to experience". Their study also questions the added value of mass tourism as supplied by the cruise sector, entraining concern as to its effect on the visitation experience of air tourists, and ultimately impacting the substantial producer surplus from this sector. This will further limit the economic benefits of the promotional strategies favoring cruise tourism (Bresson and Logossah, 2011).

Based on this study, a precautionary approach to promoting further expansion of cruise tourism, and the use of a tangible environmental value in decision-making analyses are recommended.

Accommodating the changing cruise ship industry may not lead to responsible tourism, nor create 
economic, social and environmental sustainability, and may in fact increase the current air versus cruise tourist imbalance with a limited increase in on-island visitor spending. On the other hand, attention to environmental features of the tourism experience can result in an outward shift of tourism demand thereby increasing producer surplus. However, for a more comprehensive evaluation of tourism impact on coral reefs, the magnitude and incremental environmental and social operational impacts such as sewage, waste management, on-island transport, water demand and others need to be considered for both sectors of the industry. This study illustrates that Reef-associated tourism revenue to the island is closely linked to Bermuda's coral reef system; more specifically, it is positively related to sustainable environmental conditions of this ecosystem, proving true for both the cruise and air tourism sectors.

\section{References}

Bermuda Department of Statistics (2011). Tourism Satellite Account (TSA) Report. Bermuda.

Bermuda Department of Tourism (2014). Visitor profile 2013. Government of Bermuda, Bermuda.

Bermuda Department of Tourism (2012). National Tourism Plan. Government of Bermuda, Bermuda.

Bermuda Department of Tourism (2007a). Visitor profile 2007. Government of Bermuda, Bermuda.

Bermuda Department of Tourism (2007b). Visitor 2007 year end flash report. Government of Bermuda, Bermuda.

Brander L., H. Cesar and P.J.H. van Beukering (2007). The recreational value of coral reefs: A meta analysis. Ecological Economics 63(1): 209-218.

Bresson, G. and K. Logossah (2011). Crowding-out effects of cruise tourism on stay-over tourism within the Caribbean. Non-parametric panel data evidence, Tourism Economics 17(1): 127158.

Brouwer, R., Luke Brander and Pieter van Beukering (2008). "A convenient truth": air travel passengers' willingness to pay to offset their CO2 emissions. Climatic Change. 90:299-313.

Burke L., S. Greenhalgh, D. Prager, and E. Cooper (2008). Coastal Capital - Economic Valuation of Coral Reefs in Tobago and St. Lucia. WRI Report. Washington DC.

Carleton C. and Lawrence K.S. (2005). Economic Valuation of Environmental Resource Services in the Turks and Caicos Islands. Prepared for the Government of the Turks and Caicos Islands by Nautilus Consultants Ltd., Peebles, UK.

Carr, L. and R. Mendelsohn (2003). Valuing coral reefs: a travel cost analysis of the Great Barrier Reef. Ambio 32(5): 353-357. 
Cesar, H.S.J. and P.J.H. van Beukering (2004). Economic valuation of the coral reefs of Hawaii. Pacific Science, 58(2): 231-242.

Freeman III, A.M. (2003). The measurement of environmental and resource values: theory and methods. Resources for the Future. Washington DC.

Glasson, J., Godfrey, K., and Goodey,B. (1995). Towards Visitor Impact Management: Visitor Impacts, Carrying Capacity and Management Responses in Europe's Historic Towns and Cities. Avebury, England.

Jaap, W.C. (2000). Coral reef restoration. Ecological Engineering 15:345-364

Jones, R.J. (2011). Environmental effects of the cruise tourism boom: sediment resuspension from cruise ships and the possible effects of increased turbidity and sediment deposition on corals (Bermuda).Bulletin Marine Science 87:659-679

Jones, R.J. (2007).Chemical contamination of a coral reef by the grounding of a cruise ship in Bermuda. Marine Pollution Bulletin 54:905-911

Lewis, R.R., M.J. Durkao, M.D. Moffler, R.C. Phillips (1985). Seagrass meadows of Tampa Bay: a review. In: Treat et al. (eds). Proceedings, Tampa Bay Area Scientific Information Symposium. Burgess Publishers Co. Inc., Minneapolis, MN. 210-246.

Johnson, D. (2002). Environmentally sustainable cruise tourism: a reality check. Marine Policy 26: 261270.

Kido, A. and T. Kido (2008). Derrama económica del turista de cruceros en el municipio de José Azueta, Guerrero. Revista Nicolaita de Estudios Económicos. III(1): 87-102.

Luckhurst, B. (1994). A Fishery-Independent assessment of Bermuda's Coral Reef fish stocks by diver census following the fish pot ban- A Progress Report, 1994. Proceedings of the 46th Gulf and Caribbean Fisheries Institute. pp. 309-323.

McElroy, J. (2003). Tourism development in small islands across the world. Geografiska Annaler 85B(4): 231-242.

Murdoch, T.J. (2007). A Functional Group approach for predicting the composition of hard coral assemblages in Florida and Bermuda. Ph.D. Dissertation University of South Alabama, Mobile AL, USA. 326pp.

Patullo, P. (2004). Sailing into the sunset: the cruise ship industry. In: Gmelch, S.B., (ed.) tourists and tourism: a reader. Long Grove, waveland Press IN., p. 339-358.

Pearce, D. and K. Turner (1990). Economics of natural resources and the environment. Harvester Wheatsheaf. Herfordshire (UK). 
Pham, K.N. and V.H.S. Tran (2001). Analysis of the recreational value of the coral-surrounded Hon Mun Islands in Vietnam. EEPSEA. Ho Chi Minh City, Vietnam.

Price, A.R.G. (2006). Cruise ships and sustainability in Bermuda: A preliminary evaluation. Bermuda National Trust Report. Industrial Economics Incorporated. Cambridge. p.44.

Precht, W.F. (1998). The art and science of reef restoration. Geotimes 1:16-20

Rowe, R.D., Schulze, W.D. and Breffle, W.S. (1996). A test for payment card biases. Journal of Environmental Economics and Management, 36: 324-344.

Sarkis, S. (1999). Report on the potential impacts of cruise ships on Bermuda's environment. Bermuda National Trust. p.46

Sarkis, S., P.J.H. van Beukering and E. McKenzie (eds.) (2010). Total Economic Value of Bermuda's Coral Reefs: Valuation of Ecosystem Services. Technical Report, Department of Conservation Services, Government of Bermuda, Bermuda. 199 pages

Seidl, Andrew, F Guiliani and Lawrence Pratt, (2007). Cruising for Colones: cruise tourism economics in Costa Rica, Tourism Economist 13(1), 67-85.

Shamsub, H., W. Albrecht, R. Dawkins. (2006). Relationship between cruise-ship tourism and stay-over tourism: a case study of the shift in the Cayman Islands' tourism strategy. Tourism Analysis 11:95-104

Smith, S.R., S. Sarkis, T.J.T. Murdoch, E. Weil, A. Croquer, N. Bates, R.J. Johnson, S. de Putron and A.J. Andersson (2013). Threats to Bermuda's coral reefs. In: Coral Reefs of the United Kingdom Overseas Territories. Ed. C.R. Sheppard. Springer. 173-188

Van Beukering, P.J.H., Brander, L., Tompkins, E. And McKenzie, E. (2007a). Valuing the environment in small islands. An environmental economics toolkit. Joint Nature Conservation Committee. Peterborough (UK).

Van Beukering, P.J.H. and H.S.J. Cesar (2004) Ecological Economic Modeling of Coral Reefs: Evaluating Tourist Overuse at Hanauma Bay and Algae Blooms at the Kihei Coast, Hawaii. Pacific Science, 58(2): 243-260.

Von Bodungen B., T.D. Jickells, S. Robertson Smith, J.A.D. Ward, and G.B. Hillier (1982). The Bermuda Marine Environement. Volume III. BBSR Special Publication No. 18. Bermuda Institute of Ocean Sciences, Bermuda. p.123.

Teye, V.B. (2006). Cruise sector policy in a tourism-dependent island destination: The Case of Bermuda. In: Cruise ship tourism. Ed. R. K. Dowling. CABI publishing, UK: 51-62 
Tribe, J. (2011). The Economics of recreation, leisure and tourism. Fourth edition. Elsevier publications, Oxford UK. 500 pages

Weeden, C., J. Lester, and M. Thyne (2011). Cruise Tourism: Emerging Issues and implications for a maturing industry. Journal of Hospitality and Tourism Management, 18: 26-29.

Woodward, R. and Wui, Y. (2001). The economic value of wetland services: a meta analysis. Ecological Economics 37: 257-270.

World Bank (2008). World Development Indicator. Washington DC. 
Appendix: Descriptive Statistics

\begin{tabular}{|c|c|c|c|c|}
\hline Variable & Mean & $\begin{array}{l}\text { Standard } \\
\text { Deviation }\end{array}$ & Minimum & Maximum \\
\hline $\begin{array}{l}W T P_{R} \\
(278)\end{array}$ & 31.04 & 33.55 & 1 & 200 \\
\hline $\begin{array}{l}\text { WTPU } \\
(407)\end{array}$ & 21.20 & 31.25 & 0 & 200 \\
\hline $\begin{array}{l}\text { Reef Importance }(s / d) \\
(150)\end{array}$ & 3.26 & 1.01 & 1 & 5 \\
\hline $\begin{array}{l}\text { Relative Reef Importance }(s / d) \\
(150)\end{array}$ & 1.73 & 0.69 & 0.43 & 5 \\
\hline $\begin{array}{l}\text { Reef Importance (v) } \\
(407)\end{array}$ & 2.24 & 0.75 & 1 & 5 \\
\hline $\begin{array}{l}\text { Relative Reef Importance }(s / d) \\
\text { (407) }\end{array}$ & 0.92 & 0.39 & 0.28 & 3.67 \\
\hline $\begin{array}{l}\text { Airplane Tourism } \\
\text { (407) }\end{array}$ & 0.49 & 0.50 & 0 & 1 \\
\hline $\begin{array}{l}\text { Method of pay (per Visit) } \\
\text { (278) }\end{array}$ & 35.28 & 47.08 & 0 & 1 \\
\hline $\begin{array}{l}\text { Duration of Visit } \\
(407)\end{array}$ & 0.004 & 0.02 & 8 & 760 \\
\hline $\begin{array}{l}\text { Income } \\
(405)\end{array}$ & 11.47 & 0.68 & 9.43 & 13.48 \\
\hline $\begin{array}{l}\text { Age } \\
(404)\end{array}$ & 47.72 & 13.72 & 18 & 81 \\
\hline $\begin{array}{l}\text { Mandatory Contribution } \\
\text { (279) }\end{array}$ & 0.46 & 0.50 & 0 & 1 \\
\hline
\end{tabular}

